Caris-Verhallen, W.M.C.M., Kerkstra, A.

Continuity of care for patients on a waiting list for institutional long-term care.

Health and Social Care in the Community: 9, 2001, nr. 1, p. 1-9

Postprint Version 1.0

Journal website http://dx.doi.org

Pubmed link http://www.ncbiënlm.nih.gov/entrez/query.fcgi?cmd=Retrieve\&db=pubmed\&do $\mathrm{pt}=$ Abstract\&list uids=11560716\&query $\mathrm{hl}=45 \&$ itool=pubmed docsum

DOI 10.1046/j.1365-2524.2001.00274.x

Correspondence - W.M.C.M. Caris-Verhallen - Netherlands Institute of Primary Health Care (Nivel) PO Box 1568 - 3500 BN Utrecht - the Netherlands - E-mail: w.caris@nivel.nl

\title{
Continuity of care for patients on a waiting list for institutional long-term care
}

\author{
WILMA M.C.M. CARIS-VERHALLEN ${ }^{1}$ PHD RN AND ADA KERKSTRA ${ }^{2}$ PHD \\ 1 Research Fellow, Department of Nursing and Caring Research, Netherlands Institute of Primary \\ Health Care, Utrecht and \\ 2 Head of Department of Nursing and Caring Research, Netherlands Institute of Primary Health Care, \\ Utrecht, the Netherlands
}

\begin{abstract}
The aim of this study was to examine patients' satisfaction with continuity of care while on a waiting list for residential care or nursing home care. Two hundred and seventy-eight patients participated in the study, all living in the community setting of two cities in the Netherlands. These patients were positively assessed and on a waiting list for admission in a nursing home or a residential home. The respondents were interviewed by telephone, using a structured questionnaire.

From the results, it appeared that people waiting for residential care are in general over 80 years of age and dependent on help for their daily activities. They used several types of home care facility, such as home help services, home nursing and meals on wheels. Patient satisfaction was moderately high as regards the supply of substitute care and the length of time it took to receive a home care package. There was dissatisfaction, however, with the coordination of care and the amount of information on procedures regarding the waiting list. Patients on the waiting list also reported a lack of guidance in case of problems and would not know where to turn to if their situation became more severe. The establishment of a service desk to provide information or real help in these circumstances is recommended.
\end{abstract}

\section{INTRODUCTION}

Because of improvements in health care and a higher standard of living, people in the West are living longer. Both the absolute numbers of older people and the proportion of the total populations which they constitute are increasing, and these increases are expected to continue for the foreseeable future (Glendinning 1998). Currently, people over the age 65 make up 13.1\% of the population of the Netherlands, but, by the year 2015, elderly people are expected to represent $17.3 \%$ of the population (RIVM 1997).

This demographic trend has an impact on services for elderly people. There is a growing demand for long-term care facilities such as residential care and nursing homes. Consequently, policy-makers throughout the West are faced with the question of how long-term care for dependent elderly people is to be funded (Davey 1998).

A residential home for elderly people in the Netherlands is an institution providing living conditions adjusted to the needs of residents, usually requiring no more nursing care than can be given by a 
visiting nurse (Meijer 1998). Nursing homes are defined as institutions providing nursing care 24 hours a day, assistance with activities of daily living and mobility, psycho-social and personal care, paramedical care such as physiotherapy and occupational therapy, as well as room and board (Ribbe 1993). In 1998 there were 56740 beds available in Dutch nursing homes, that is 27 beds per 1000 people aged 65 and above. In addition, in 1998 the number of places for senior citizens in homes for elderly people was 113970 , that is 54 places for every 1000 of the population aged 65 and above (Ministry of Health, Welfare \& Sports 1999a, CBS 1999).

The provision of these types of institutional long-term care is in trouble because demand exceeds availability. In 1998, nationwide, 8260 elderly people were waiting for admission to a nursing home and 20300 were waiting for a place in a home for elderly people. The mean waiting time for a nursing home was about 7 weeks for somatic patients and 18 weeks for psycho-geriatric patients. Furthermore, people had to wait about 9.5 months for admission to a home for elderly people (Ministry of Health, Welfare \& Sports 1999b). The Dutch government aims to control the growing demand by formalizing and standardizing the needs assessment, that is the process of determining the patient's needs for the health services to which they are entitled (Maarse \& Van der Made 1998). One of the first projects concerning this standardized needs assessment took place in Amsterdam, where municipal assessment committees are in charge of needs assessment for people requiring care in a home for elderly people or a nursing home. Yet this formalized needs assessment is not enough to meet the need for institutional care and, as a consequence, waiting lists, with people already positively assessed on needs but still waiting in the community for the actual provision of care in an institution, are growing.

Elderly people waiting for institutional care in the Netherlands often resort to home care organizations and provision of adequate care for these persons is a general aim of health care providers. In order to help people to maintain life in the community, there are a variety of care services. In addition to home care, including district nursing, personal care and domestic care, there is also day care and night care provided by homes for elderly people or nursing homes. Using the latter, patients receive shelter for a few days or a few nights per week, while still living at home. Apart from that, there are also residential institutions that provide some alternative forms of home care. For instance, professionals from residential homes visit people at home and provide general support, sometimes supplemented by personal care or domestic care. In receiving these forms of alternative care, patients have to deal with many different care providers. This entails risks of fragmenting the organization of care, lack of information and lack of coordination. A major concern of health care providers is therefore how to assure continuity of care for people on waiting lists. This has led to the development of local initiatives directed to quality assurance in general and more specifically at continuity of care and information supply. Cooperating health care organizations in Amsterdam have concluded agreements to assure continuity of care and to improve information supply for patients waiting for institutional care.

Collaborating nursing homes in Utrecht City started a project called 'waiting-list services'. Within this project, a nursing team, attached to the participating institutions, ensures that waiting-list patients with high priority receive appropriate care to bridge the waiting period before their admission to the nursing home.

National policy and these local programmes led to a need to explore how activities relating to a formalized needs assessment and how local activities relating to improving the continuity of care are delineated. In this paper we specifically explore the continuity of care from the patients' perspective. We make an inventory of difficulties and problems experienced by patients while waiting for institutional long-term care, in order to obtain information about how interventions can take place. Results can also be considered as baseline information to define effects of interventions to improve continuity of care in the near future.

\section{Theoretical background}

The care process, which departs from the patient's needs, is characterized by successive phases: demand, needs assessment, planning, delivery of care and evaluation. The process has a cyclic nature, during which continuous exploration takes place to define whether actions contribute to goal attainment. During the final phase there are checks to see whether the objectives have been achieved. When objectives are not achieved or a new need is perceived, the care process restarts. If the patient is enabled to cope without (nursing) care, the care process is considered as completed. 
In the context of quality of care an important concept is 'continuity in the care process'. Shortell (1976) defines the concept of continuity of care as 'the extent to which services are received as part of a coordinated and uninterrupted succession of events consistent with the needs of the patient'.

In this definition three different aspects are to be discerned (Casparie et al. 1998):

-The ongoing tuning of health care to the needs of the patient;

- Coordination of care provided at a given moment in time;

- Coordination of care in case of referral.

The first two aspects are also the aims of the local projects mentioned before, and consequently form the starting point for this study.

\section{Aim of the study}

The aim of this descriptive study is to explore how patients experience the standardized process of needs assessment and how they perceive the continuity of care while being on a waiting list for residential care.

Specifically, the following research questions were addressed:

- To what extent are patients informed about the course of the caring process in general and specifically about the needs assessment and the waiting list?

- To what extent do patients on a waiting list receive care tailored to their individual needs?

- To what extent do patients on a waiting list experience coordination of care when care is provided by different providers?

\section{METHODS}

\section{Sample}

A sample of 980 patients, who were registered on a waiting list for long-term care in nursing homes or homes for elderly people in Amsterdam and Utrecht, were sent a letter to ask them to participate in the study. They were informed about the research, and were asked to give informed written consent for themselves or through an informal caregiver. After receiving consent the respondents were approached by telephone and a 30-minute structured interview was conducted. Of the total sample, $52 \%$ responded and 322 agreed to an interview (33\%). As a result of inaccessible phone numbers or last minute refusals, finally 278 (28\%) patients or their informal caregivers participated in the study.

The respondents comprised 164 non-institutionalized persons waiting for residential care in a home for the aged, with a mean age of 84 years, and 114 patients waiting for admission in a nursing home (mean age 82). Table 1 gives an overview of respondents' characteristics. Approximately threequarters of the respondents lived alone and about a quarter lived with a spouse or a family member. The education level of the total group was quite low, about half of the group only had only been to primary school.

\section{[ TABLE 1 ]}

\section{Measuring instruments}

The structured interview consisted of several existing questionnaires. Enquiries were made about demographic characteristics (marital status, education, living alone, etc.), the ability to provide self care, the care received while on a waiting list for institutional care, patients' perception of the amount of information obtained about procedures relating to waiting list and patients' perception of continuity of care.

\section{Self care ability}

Patients' self care ability was assessed on two scales: activities of daily living (ADL), covering items like washing oneself, eating, using the toilet, and instrumental activities of daily living (IADL), like bed making, preparing dinner or the house work. Both scales were developed by Kempen \& Suurmeijer (1990). Following these authors the scores were dichotomized. The original score 1 and score $2(1$ = to perform the activity independently and easily; 2 = independently but with some difficulty) were joint scores. Score 3 (dependent on others) remained unaltered. 


\section{Inventory of caring services}

Twelve items described the caring services and a number of additional services (like meals on wheels and alarm system) that patients could receive while being on a waiting list for residential care. Another 12 items assessed whether or not patients received care that was tailored to their individual needs, while waiting for institutional care.

\section{Patients' satisfaction on continuity of care}

Twelve items described patients' satisfaction concerning application and assessment. For example 'what is your opinion about the amount of information you received' $(1=$ excellent, 6 = very bad). In addition, items were included to assess how patients evaluated the continuity of each specific type of care they received. These items were formulated relying on the QUOTE-instrument (Sixma et al. 1998) and on the questionnaire Continuity of Care (Casparie et al. 1998).

\section{Analysis}

Mainly descriptive statistics were used because of the descriptive character of this study. We calculated the percentage of less satisfied patients for each item to study patients's satisfaction with continuity of care.

\section{RESULTS}

\section{Functional status of patients on a waiting list}

Table 2 shows that $84 \%$ of respondents waiting for admission to a home for elderly people depended (partly) on others for activities of daily living. Furthermore, except for preparing lunch or breakfast, most respondents waiting for a residential home for elderly people also needed help with the housework; 65\% were dependent on others for three or more IADL activities.

\section{[ TABLE 2 ]}

The functional status of people waiting for admission to a nursing home is even more serious. All respondents experience one or more difficulties in activities of daily living. Nearly all of them depend on others for personal hygiene care and $80 \%$ of them encountered difficulties on five or more IADL items.

\section{Satisfaction with the assessment procedure}

All people who are in need of institutional long-term care can apply by telephone for an assessment procedure in a municipal agency. No medical referral is required, and people receive an assessment visit. During this visit individuals' needs and desires are discussed and assessed.

The results show that in general, people waiting for institutional care are satisfied about the room they get during the assessment visit and the opportunity they have to make their wishes clear and to explain their situation (Table 3). The majority of the respondents think that their preferences are taken into account. The amount of information people receive concerning waiting-list procedures was rated by $20 \%$ as poor. About one third of all respondents reported that they had no information about the period between assessment and actual care supply. For instance they did not know where to go when problems were getting more serious or when their need for care was increasing.

\section{[ TABLE 3 ]}

\section{Actual use of (home) care services}

Older people waiting for a place in an institution often make use of a variety of health care services at home. Table 4 shows what kinds of services are provided. Nearly two third of the people waiting for residential care rely on domestic care provided by home-help services. Twenty-eight percent depend on professional services for personal care and 17\% receive district nursing. Additional services are also frequently used by people waiting for residential long-term care. Twenty-three percent of the respondents waiting for a home for elderly people did not use home care. Most of them appealed to informal caregivers. 


\section{[ TABLE 4 ]}

If we look at the results of people waiting for a bed in a nursing home it seems that these persons were making use of fewer home care services than their counterparts waiting for residential care. In fact, nearly half of them were already institutionalized. More specifically, $19 \%$ of all people waiting for a nursing home were in hospital. Their situation was too serious, so they could not go home without an extensive package of home care; as a result, they had to stay in hospital. Another $26 \%$ were already in a home for elderly people but were in need of the more comprehensive package of care provided in a nursing home. The remaining people waiting for admission to a nursing home used various homecare services. Nearly a quarter of the respondents used part residential care, meaning that they received day care or night care a few times a week. This type of care is especially suitable in situations were there is a need to relieve informal caregivers who are responsible for people suffering from dementia.

When asked, $81 \%$ of people waiting for institutional care received replacement home care immediately after the needs assessment, and 7\% received care three weeks after the assessment. Sixtyfive percent were satisfied about the amount of care received. About one quarter of the respondents evaluated the package of replacement care as insufficient. In particular they had a need for domestic care.

\section{Patients' satisfaction with the continuity of care}

As the results showed, while waiting for institutional care, elderly people living in the community were to a large extent supported by community-based services such as district nursing, home help and social assistance. Therefore they were asked how they judged the quality of care provided by these services. In the scope of this study, attention was especially paid to continuity of care. Table 5 shows the results for each different discipline. On average one quarter of the participants in the study felt that caregivers within a discipline were working at cross-purposes and one fifth said they received inconsistent information. About two-thirds of the patients responded that caregivers only rarely discussed and evaluated the care provided. In four disciplines about $40 \%$ of the patients did not know where to report a complaint. The home-help services formed a favourable exception on this topic.

\section{[ TABLE 5 ]}

Continuity of care is especially questioned when different disciplines are concerned in home care. In Table 5, it has already been shown that people who relied on one care discipline had to deal with three to six different caregivers. These figures did not include exceptional situations, such as turnover, holidays and staff illness. Consequently, when people received home-help services, district nursing and attended day care, there was a possibility that they would have to deal with $10-15$ different caregivers per week. In these cases the organization of care is at risk and patients may experience a lack of information and a lack of coordination. People who received care from different sources were asked how they judged continuity of care. The results are presented in Table 6.

\section{[ TABLE 6 ]}

As regards coordination of care, one third of the patients receiving both district nursing and homehelp services reported that cooperation between the two disciplines left something to be desired. It appeared that care providers from these different disciplines take too little notice of each others' targets. The division of tasks between the two groups of professionals was clear for most patients. However, $18 \%$ of them did not know who was responsible for the coordination of care.

People receiving both partly residential care and home care were most vulnerable to a lack of continuity. Forty-four percent of them were less satisfied about the cooperation between the professionals of these different institutions. A quarter of them did not have a clear picture about the division of tasks and one fifth of the patients felt that caregivers from the different disciplines were working at cross purposes. 


\section{DISCUSSION}

The results presented in this paper reflect people's perceptions of continuity of care while being on a waiting list for long-term institutional care. Firstly, attention was paid to the standardized needs assessment procedure. Secondly, we investigated how respondents rated the fit and continuity of substitute care.

\section{Overview of the results}

Although people reported that they were reasonably satisfied with the assessment procedure, there appeared to be a shortage of information supply on waiting list procedures. In particular, advice was lacking about how to behave when problems became aggravated. This reflects a serious problem, because the waiting period for admission to a residential home may amount to one or two years.

With respect to care tailored to the individual's needs, in the first instance it appeared that substitute care in the community fits reasonable well. Only a minority of people had a need for additional care. Yet a related problem is underexposed here. A considerable number of people, waiting for admission to a nursing home, stayed in a hospital because there was no suitable package of care outside the hospital. In the Netherlands this is called 'the wrong bed issue'. A 'wrong bed' is defined as a hospital bed, occupied by a patient who is not dependent on hospital care, but in anticipation for admission in a nursing home (Spreeuwenberg 1991). It goes without saying that incorrect use of hospital beds does not really accord with the individual's needs. Moreover, this is definitely not in keeping with an efficient use of health care services.

Continuity of care was threatened within the different disciplines and also when several disciplines were involved. A striking result was that health care providers rarely evaluated the care provided. This means that care providers do not assess whether care is sufficiently attuned to individual needs or find out whether the person is satisfied or not. This is a dubious result, because in discussing the care provided with individuals there is an ideal opportunity to inform people and to explain how things are organized. In that way, regular discussion of and consultation on the care process may improve the perceived continuity of care.

\section{Methodological considerations}

Although this study revealed a lot of information, some methodological issues are worth mentioning. Data was gathered using a telephone survey. This might have caused some selectivity in the population under study. The target population is in general very old. As we invited them to participate by letter, presumably the most frail segment of the population is underrepresented in the study, because they were not capable of responding or because they could not rely on an informal caregiver. Accordingly, no general conclusions can be drawn about topics such as the 'the wrong bed issue'.

Another issue was the response rate of $28 \%$. Based on results of a comparable study (van Campen et al. 1997), we anticipated such a rate by approaching a large sample (three times higher than needed). However, it can not automatically be assumed that the findings from this study apply to all community care clients waiting for institutional care.

Moreover, there is some concern about the conceptual validity of the satisfaction measures. It transpires that when people are asked to give their assessment on quality of care, that the majority express positive views (van Campen et al. 1992, van Campen et al. 1995). This `satisfaction' is open to question. Has it been properly measured? In much research into health care, gratitude plays a role when questions are asked about satisfaction. Consequently, people in this type of research often tend to give socially desirable answers (de Heer et al. 1988; Visser 1988). Following QUOTE (Sixma et al. 1998), this problem was anticipated by asking highly detailed questions about various aspects and the actual experiences of the provided care.

\section{Future directions}

As stated in the introduction of this paper, there is much activity and development in community health care. In answer to the growing demands made on health care services, a standardized needs assessment is being developed to control the demand. Moreover, health care institutions cooperate in the struggle against the fragmentation of care for people waiting for admission. In this context the present study visualizes how people perceive continuity of care and where interventions should be directed. 
Apart from a need for a more effective interagency collaboration, the most basic topic in quality assurance activities, aiming to improve continuity of care, seems to be information supply. All the following recommendations deal with information supply, which seems of special importance to people who, after an assessment, have to wait for an actual provision of care. Firstly, these people should be informed as to how they can cope with problems while waiting in the community for admission to an institution. This group of people is vulnerable and very likely to experience a decline in function or to be confronted with an aggravating situation, so the establishment of a facility to which they can turn for advice, guidance or real help is recommended.

Furthermore, the complaints procedure deserves attention. Although each health care organization in the Netherlands is obliged to establish such a procedure, care recipients seem to have too little information about it. Improvement is needed so that every person is informed on how to handle in the case of a complaint.

Finally, the relationship between caregiver and recipient deserves attention. When we think it is important that care provider and recipient get on well together, it is necessary for the care professional to supply the recipient with all relevant information. The course of the care process and evaluation of care should be discussed regularly. As we mentioned above, regular consultation, information and explanation may improve continuity of care.

\section{ACKNOWLEDGEMENTS}

This research project is financed by the Netherlands Organisation for Scientific Research (NWO), Research Programme Quality of Care (KwaZO).

\section{REFERENCES}

van Campen C., Friele R.D. \& Kerssens J.J. (1992) Methods for Assessing Patient Satisfaction with Primary Care: Review and Annotated Bibliography. NIVEL, Utrecht.

van Campen C., Kerkstra A. \& Taes C. (1997) Het Meten van Ervaren Kwaliteit van Leven van Oudere Somatische Verpleeghuispatiënten (Assessing Quality of Life in Elderly Patients Living in a Nursing Home). NIVEL, Utrecht.

van Campen C., Sixma H., Friele R.D., Kerssens J.J. \& Peters L. (1995) Quality of care and patient satisfaction: a review of measuring instruments. Medical Care Research and Review 52 (1), 109 133.

Casparie A.F., Foets M., Raaijmakers M.F. et al. (1998) Vragenlijst Continuïteit van Zorg Vanuit Patiëntenperspectief, Handleiding (Questionnaire Continuity of Care from Patients' Perspectives). VU/ Utrecht: NIVEL/Groningen: NCG, RUG, Amsterdam.

CBS (1999) Vademecum of Health Statistics of the Netherlands. CBS, Voorburg/Heerlen, the Netherlands.

Davey J.A. (1998) Exploring shared options in funding long-term care for older people. Health and Social Care in the Community 6 (3), $151-157$.

Glendinning C. (1998) Convergence or diversity in the provision of long-term care for frail older people. In: C. Glendinning (Ed.) Rights and Realities: Comparing New Developments in Long-Term Care for Older People , pp. 1 - 9. The Policy Press, Bristol.

de Heer A., Visser A.Ph. \& Visschedijk H. (1988) De tevredenheid van de dankbare patiënt in het ziekenhuis (Satisfaction of the grateful patient in hospital). In: A. Ph. Visser (Ed.) Onderzoek Naar de Tevredenheid van Ziekenhuispatiënten, Doel, Methode En Beleid (Research into Patient Satisfaction: Goals, Methods and Policy) , pp. 138 - 154. De Tijdstroom, Lochem.

Kempen G.I.J.M. \& Suurmeijer T.P.B.M. (1990) The development of a hierarchical polychotomous ADL-IADL scale for noninstitutionalized elders. Gerontological Society of America 30 (4), 497 - 502.

Maarse H. \& van der Made J. (1998) Cost containment and the right to health care. European Journal of Public Health 8 (2), 119-126.

Meijer A. (1998) Nursing homes in Europe: A Comparative Study of the Organization and Financing of Nursing Homes in Five European Countries. Agricultural University, Wageningen.

Ministry of Health Welfare and Sports (1999a) Zorgnota 2000 (Program Care 2000). SDU, Den Haag. Ministry of Health Welfare and Sports (1999b) Plan van Aanpak. Wachtlijsten in de Verpleging en Verzorging (Strategies on Waiting Lists in Nursing Care). SDU, Den Haag.

Ribbe M.W. (1993) Care for the elderly: the role of the Nursing Home in the Dutch Health Care System. International Psychogeriatrics 5 (2), 213 - 222. 
Caris-Verhallen, W.M.C.M., Kerkstra, A.

Continuity of care for patients on a waiting list for institutional long-term care.

Health and Social Care in the Community: 9, 2001, nr. 1, p. 1-9

RIVM. (Rijksinstituut voor Volksgezondheid en Milieu) (1997) Volksgezondheid Toekomst Verkenning 1997: VII Gezondheid En Zorg in de Toekomst (Public Health Prospectives 1997: VII Health and care in the future). RIVM, Bilthoven.

Shortell S.M. (1976) Continuity of medical care: conceptualization and measurement. Medical Care 14 (5), 377 - 391.

Sixma H., van Campen C., Kerssens J.J. \& Peters L. (1998) De QUOTE Vragenlijsten: Kwaliteit van Zorg vanuit Het Patiënten- Perspectief; Vier Nieuwe Meetinstrumenten. (The QUOTE Questionnaire: Quality of Care from Patients' Perspectives). NIVEL, Utrecht, NWO, VWS, Den Haag.

Spreeuwenberg C. (1991) Het verkeerde bed (the wrong bed). Medisch Contact 46 (7), 195.

Visser A.Ph. (1988) De Meting van de Tevredenheid van Ziekenhuispatiënten: Ontwikkeling en

Betekenis van een vragenlijst (Measuring hospital patient satisfaction). In: A. Ph. Visser (Ed.)

Onderzoek Naar de Tevredenheid van Ziekenhuispatiënten, Doel, Methode En Beleid (Research into Patient Satisfaction: Goals, Methods and Policy) , pp. 25 - 51. De Tijdstroom, Lochem.

\section{TABLES}

Table 1 Overview of patients' characteristics

\begin{tabular}{|c|c|c|c|c|}
\hline \multirow[b]{2}{*}{ Characteristics } & \multicolumn{2}{|c|}{$\begin{array}{l}\text { Waiting for a home for } \\
\text { elderly people }(n=164)\end{array}$} & \multicolumn{2}{|c|}{$\begin{array}{l}\text { Waiting for a nursing } \\
\text { home }(n=114)\end{array}$} \\
\hline & $n$ & $\%$ & $n$ & $\%$ \\
\hline \multicolumn{5}{|l|}{ Gender } \\
\hline Female & 129 & (79) & 70 & (61) \\
\hline Mean age & 84 & & 82 & \\
\hline Number of months on waiting list (median) & 10 & & 45 & \\
\hline \multicolumn{5}{|l|}{ Living arrangement } \\
\hline Alone & 138 & $(84)$ & 64 & $(56)$ \\
\hline With spouse & 17 & (10) & 37 & (32) \\
\hline With family member & 8 & (5) & 10 & (9) \\
\hline With others & 1 & (1) & 3 & (3) \\
\hline \multicolumn{5}{|l|}{ Residence } \\
\hline At home & 164 & $(100)$ & 56 & (49) \\
\hline Hospital & & & 15 & (13) \\
\hline Home for elderly people & & & 43 & (38) \\
\hline \multicolumn{5}{|l|}{ Level of education } \\
\hline None/elementary education & 90 & (55) & 51 & (45) \\
\hline Lower (vocational) education & 23 & (14) & 20 & (18) \\
\hline Intermediate (vocational) education & 36 & (22) & 28 & $(24)$ \\
\hline Higher education & 15 & (9) & 15 & (13) \\
\hline
\end{tabular}


Caris-Verhallen, W.M.C.M., Kerkstra, A.

Continuity of care for patients on a waiting list for institutional long-term care.

Health and Social Care in the Community: 9, 2001, nr. 1, p. 1-9

Table 2 Percentage of patients dependent on others while living in the community and waiting for institutional care

\begin{tabular}{|c|c|c|}
\hline & $\begin{array}{l}\text { Waiting for a home for } \\
\text { elderly people }(n=164)\end{array}$ & $\begin{array}{l}\text { Waiting for a nursing } \\
\text { home }(n=114)\end{array}$ \\
\hline & $\%$ & $\%$ \\
\hline \multicolumn{3}{|l|}{ ADL items } \\
\hline Getting in /out of bed & 4 & 47 \\
\hline Washing face/ hands & 6 & 44 \\
\hline Care of feet $/$ nails & 75 & 97 \\
\hline \multicolumn{3}{|l|}{ Washing oneself completely } \\
\hline (bathing, showering) & 37 & 90 \\
\hline Dressing & 9 & 75 \\
\hline Using the toilet & 3 & 54 \\
\hline $\begin{array}{l}\text { Sitting down and arising from a chair } \\
\text { Moving inside the house, }\end{array}$ & 4 & 40 \\
\hline on the same floor & 2 & 37 \\
\hline Up/down stairs & 40 & 69 \\
\hline Moving outdoor on flat ground & 34 & 77 \\
\hline Eating/drinking & 2 & 25 \\
\hline \multicolumn{3}{|l|}{ Total number of $A D L$ difficulties } \\
\hline None & 16 & 0 \\
\hline $1-2$ & 50 & 14 \\
\hline $3-4$ & 26 & 15 \\
\hline $5-6$ & 5 & 23 \\
\hline $7-8$ & 2 & 11 \\
\hline $9-11$ & 2 & 38 \\
\hline \multicolumn{3}{|l|}{ IADL items } \\
\hline Bed making & 52 & 84 \\
\hline 'Light' house work & 30 & 75 \\
\hline Washing/ironing clothes & 57 & 86 \\
\hline Heavy house work & 86 & 85 \\
\hline Preparing lunch / breakfast & 9 & 73 \\
\hline Preparing dinner & 45 & 88 \\
\hline Shopping & 59 & 91 \\
\hline \multicolumn{3}{|l|}{ Total number of IADL difficulties } \\
\hline None & 9 & 3 \\
\hline $1-2$ & 27 & 4 \\
\hline $3-4$ & 34 & 13 \\
\hline $5-7$ & 31 & 80 \\
\hline
\end{tabular}

Table 3 Patients' rating of quality of care aspects during the formalized assessment procedure, $n=278$

\begin{tabular}{|c|c|c|c|}
\hline & $\begin{array}{l}\text { Sufficient/good/ } \\
\text { excellent }\end{array}$ & Neutral & $\begin{array}{l}\text { Bad/very } \\
\mathrm{bad}\end{array}$ \\
\hline Quality aspects & $\%$ & $\%$ & $\%$ \\
\hline $\begin{array}{l}\text { Room for the patient to explain the needs, } \\
\text { the demands and the situation }(n=216)\end{array}$ & 90 & 7 & 3 \\
\hline $\begin{array}{l}\text { Provision of information on various care } \\
\text { possibilities }(n=212)\end{array}$ & 63 & 20 & 17 \\
\hline $\begin{array}{l}\text { Room for the patient to make choices on } \\
\text { care facilities }(n=222)\end{array}$ & 75 & 16 & 9 \\
\hline $\begin{array}{l}\text { Taking into account patients' preferences } \\
\quad(n=229)\end{array}$ & 74 & 12 & 14 \\
\hline $\begin{array}{l}\text { Provision of information on waiting list } \\
\text { procedures }(n=248)\end{array}$ & 69 & 11 & 20 \\
\hline $\begin{array}{l}\text { Provision of information on course } \\
\text { between needs assessment and } \\
\text { actual supply of care }(n=247)\end{array}$ & 53 & 14 & 33 \\
\hline
\end{tabular}


Caris-Verhallen, W.M.C.M., Kerkstra, A.

Continuity of care for patients on a waiting list for institutional long-term care.

Health and Social Care in the Community: 9, 2001, nr. 1, p. 1-9

\begin{tabular}{lll}
\hline & $\begin{array}{l}\text { Waiting for a home } \\
\text { for elderly people } \\
(n=164) \\
\%\end{array}$ & $\begin{array}{l}\text { Waiting for } \\
\text { a nursing home } \\
(n=114) \\
\%\end{array}$ \\
Type of care & & \\
\hline Home care & 63 & 20 \\
Domestic care & 28 & 24 \\
Hygiene care & 17 & 11 \\
Nursing care & 12 & 24 \\
Partly residential care at day & 0 & 3 \\
Partly residential care at night & & 13 \\
Additional services & 34 & 20 \\
Meals on wheels & 55 & 1 \\
Alarm system & 17 & 25 \\
Handyman services & 55 & 79 \\
Technical adaptations and aids & 69 & 46 \\
Informal care & 0 & \\
Temporarily resident in hospital or & & \\
a home for elderly people & & \\
\hline
\end{tabular}

Table 4 Use of home care and home care services by people waiting for institutional care

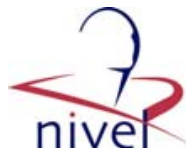

Table 5 Patients' assessment with aspects of continuity of care

\begin{tabular}{|c|c|c|c|c|c|}
\hline Aspects & $\begin{array}{l}\text { District } \\
\text { nursing } \\
(n=50)\end{array}$ & $\begin{array}{l}\text { Home help } \\
\text { services } \\
(n=133)\end{array}$ & $\begin{array}{l}\text { Partly } \\
\text { residential care } \\
(n=43)\end{array}$ & $\begin{array}{l}\text { Hospital } \\
(n=15)\end{array}$ & $\begin{array}{l}\text { Home for } \\
\text { the elderly } \\
(n=43)\end{array}$ \\
\hline Number of care providers a patient has to deal with & 5 & 3 & 5 & 6 & 5 \\
\hline Less satisfied about this number of care providers & $37 \%$ & $15 \%$ & $3 \%$ & $5 \%$ & $23 \%$ \\
\hline Less satisfied about cooperation of care providers & $27 \%$ & $17 \%$ & $3 \%$ & $11 \%$ & $28 \%$ \\
\hline Inconsistency of information given by care givers & $24 \%$ & $19 \%$ & $14 \%$ & $7 \%$ & $19 \%$ \\
\hline Feels care providers working at cross purposes & $30 \%$ & $26 \%$ & $16 \%$ & $20 \%$ & $28 \%$ \\
\hline Less satisfied about turnover care providers & $33 \%$ & $24 \%$ & $3 \%$ & $21 \%$ & $31 \%$ \\
\hline $\begin{array}{l}\text { Less satisfied on continuity of care in case of } \\
\text { replacement of personnel }\end{array}$ & $22 \%$ & $11 \%$ & $0 \%$ & $5 \%$ & $53 \%$ \\
\hline $\begin{array}{l}\text { Less satisfied with answers on questions about the } \\
\text { care provided }\end{array}$ & $14 \%$ & $8 \%$ & $6 \%$ & $5 \%$ & $21 \%$ \\
\hline $\begin{array}{l}\text { Caregivers do not or only rarely evaluate the care } \\
\text { provided }\end{array}$ & $66 \%$ & $69 \%$ & $45 \%$ & $60 \%$ & $63 \%$ \\
\hline $\begin{array}{l}\text { Less satisfied about care providers keeping their } \\
\text { appointments punctually }\end{array}$ & $14 \%$ & $5 \%$ & $3 \%$ & $6 \%$ & $7 \%$ \\
\hline $\begin{array}{l}\text { Less satisfied about accessibility by telephone } \\
\text { when needed }\end{array}$ & $26 \%$ & $12 \%$ & & & \\
\hline Does not know where to report complaints & $44 \%$ & $9 \%$ & $33 \%$ & $40 \%$ & $43 \%$ \\
\hline
\end{tabular}

Table 6 Patients' assessment of continuity of care when different disciplines of care providers are concerned

\begin{tabular}{|c|c|c|}
\hline Aspects & $\begin{array}{l}\text { Cooperation of } \\
\text { district nurses and } \\
\text { home helps } \\
(n=32)\end{array}$ & $\begin{array}{l}\text { Cooperation of home care } \\
\text { providers and care providers } \\
\text { from day or night care } \\
(n=34)\end{array}$ \\
\hline Less satisfied about cooperation & $33 \%$ & $44 \%$ \\
\hline Inconsistency in information by caregivers from different disciplines & $12 \%$ & $7 \%$ \\
\hline Feels care providers from different disciplines are working at cross purposes & $32 \%$ & $20 \%$ \\
\hline Division of tasks among care providers of different disciplines is unclear & $7 \%$ & $26 \%$ \\
\hline Vagueness about which care provider is responsible for coordination of care & $18 \%$ & $13 \%$ \\
\hline
\end{tabular}

